\title{
Kepatuhan Kunjungan Posyandu dan Status Gizi Balita di Posyandu Karangbendo Banguntapan, Bantul, Yogyakarta
}

\author{
Retno Sugiyarti ${ }^{1}$, Veriani Aprilia², Febriana Suci Hati ${ }^{3}$ \\ 1,2,3 Sekolah Tinggi Ilmu Kesehatan Alma Ata Yogyakarta \\ Jalan Ringroad Barat Daya No 1 Tamantirto, Kasihan, Bantul, Yogyakarta
}

\begin{abstract}
Abstrak
Angka gizi buruk balita di Indonesia cukup tinggi mencapai 17,9\%. Dusun Karangbendo dalam 3 tahun terakhir ini memiliki kasus balita gizi buruk. Cakupan penimbangan balita mempengaruhi status gizi balita. Tingkat kehadiran posyandu di Puskesmas Banguntapan III sebesar 63,9\% dan kehadiran posyandu Dusun Karangbendo 48\%. Tujuan penelitian ini untuk mengetahui hubungan tingkat kepatuhan kunjungan posyandu dengan status gizi balita di Posyandu Karangbendo Banguntapan Bantul Yogyakarta tahun 2014. Jenis Penelitian ini adalah deskriptif analitik, dengan pendekatan cross sectional. Sampel adalah balita berumur 1-5 tahun yang berkunjung di Posyandu Karangbendo pada tanggal 2 Juli 2014 yang berjumlah 40 balita. Data diperoleh dengan data sekunder yaitu KMS balita sehingga diperoleh data kepatuhan kunjungan dan status gizi, Data dianalisis dengan uji Kendall tau. Hasil penelitian balita yang berkunjung di Posyandu Karangbendo Banguntapan sebagian besar berumur antara 13-36 bulan (70\%) dan berjenis kelamin perempuan (57,5\%). Tingkat kepatuhan kunjungan balita posyandu rata-rata $70 \%$ patuh dan termasuk dalam kategori status gizi baik (72,5\%). Hasil analisis statistik Kendall tau nilai $z_{\text {hitung }} \geq z_{\text {tabel }}$ yaitu 0,614 $\geq 0,185$ yang membuktikan adanya hubungan antara tingkat kepatuhan kunjungan posyandu dengan status gizi balita. Kesimpulan ada hubungan antara tingkat kepatuhan kunjungan posyandu dengan status gizi balita di Posyandu Karangbendo Banguntapan Bantul Yogyakarta tahun 2014.
\end{abstract}

Kata Kunci: balita, posyandu, status gizi, tingkat kepatuhan

\section{Health Post Visits Compliance and Nutritional Status of Infants at Karangbendo Banguntapan, Bantul, Yogyakarta}

\begin{abstract}
Malnutrition infants incidence in Indonesia is high about $17.9 \%$. Karangbendo in the last three years has a case of malnutrition infants. The scope of children weighing affect nutritional status of infants. Attendance of health visits in puskesmas Banguntapan III was $63.9 \%$ and Karangbendo was $48 \%$. The purpose of this study was to know relationship between health post visits compliance and nutritional status of infants at Karangbendo Banguntapan Bantul, Yogyakarta 2014. This study used descriptive analytic with cross sectional approach. The samples were 40 infants aged 1-5 years that visit Karangbendo health post on 2nd july 2014. The data of health post compliance and nutritional status were obtained by secondary data from KMS. Data were analyzed by Kendall Tau test. The results showed that most of infants aged was 13-36 months about $70 \%$ and infants women was $57.5 \%$. The average of health post visits compliance was $70 \%$ and category of nutritional status was $72.5 \%$ good. The results of the analysis statistics showed that kendall tau value were 0.614 it means that there was a relationship between health post visits compliance and nutritional status of infants. In conclusion, there was a relationship between health post visits compliance and nutritional status of infants at Karangbendo Banguntapan Bantul, Yogyakarta 2014.
\end{abstract}

Keywords: compliance rate, nutritional status, posyandu, infants

Info Artikel:

Artikel dikirim pada 12 Oktober 2014

Artikel diterima pada 12 Oktober 2014 


\section{PENDAHULUAN}

Tujuan pembangunan nasional yang tercantum dalam konsep Rencana Pembangunan Jangka Panjang Nasional (RPJMN) 2015-2019 salah satunya adalah peningkatan kualitas sumber daya manusia (SDM). Upaya peningkatan kualitas SDM dimulai dengan proses tumbuh kembang anak sejak pembuahan sampai usia dewasa muda. Pada masa tumbuh kembang ini, pemenuhan kebutuhan dasar anak seperti perawatan dan makanan bergizi dapat membentuk SDM yang cerdas, sehat dan produktif(1).

Penimbangan balita di posyandu merupakan indikator yang berkaitan dengan cakupan pelayanan gizi pada balita, cakupan imunisasi serta prevalensi gizi kurang.

Hasil Riskesdas, secara nasional menunjukkan cakupan penimbangan balita sebagai salah satu sarana pemantauan status gizi di posyandu sebesar $65,7 \%$. Frekuensi kunjungan balita ke posyandu semakin berkurang dengan semakin meningkatnya umur anak. Sebagai gambaran proporsi anak 6-11 bulan yang ditimbang di posyandu $91,3 \%$, pada anak usia $12-23$ bulan turun menjadi $83,6 \%$, dan pada usia 24-35 bulan turun menjadi $73,3 \%(2)$.

Angka penderita gizi buruk pada balita di Indonesia masih cukup tinggi. Berdasarkan hasil Riset Kesehatan Dasar pada tahun 2010 jumlahnya mencapai $17,9 \%$, diperoleh bahwa tingkat prevalensi gizi buruk yang berada di atas rata-rata nasional $(5,4 \%)$ ditemukan pada 21 provinsi dan 216 kabupaten/kota. Berdasarkan data Direktorat Bina Gizi Kementrian Kesehatan pada tahun 2010 tercatat 43.616 anak balita mengalami gizi buruk $(3,4)$.

Prevalensi balita kurang gizi di Daerah Istimewa Yogyakarta (DIY) pada tahun 2012 sebesar 8,45\% (KEP total), sudah menurun dibanding tahun 2011 sebesar $10 \%$.

Prevalensi balita dengan status gizi buruk pada tahun 2012 sebesar 0,56\% dan tahun 2011 sebesar $0,68 \%$ (menurun dibanding tahun 2010 sebesar $0,7 \%$ ). Meskipun angka gizi kurang di DIY telah jauh melampaui target nasional (persentase gizi kurang sebesar $15 \%$ di tahun 2015) namun penderita gizi buruk masih juga dijumpai di wilayah DIY.

Tahun 2008 sampai 2012 terdapat penurunan prevalensi balita dengan status gizi buruk, namun demikian perlu dilihat disparitas angka prevalensi gizi buruk di setiap wilayah kabupaten/kota dan kecamatan. Prevalensi balita gizi buruk di 4 kabupaten sudah sesuai harapan yaitu $<1 \%$, sedangkan di Kota Yogyakarta masih 1,35\%, sehingga meskipun sudah melampaui target secara nasional tetapi diharapkan seluruh kabupaten/kota di DIY sudah berada di bawah $1 \%$.
Berdasarkan laporan hasil pemantauan status gizi di kabupaten/kota tahun 2012, Balita BGM (bawah garis merah) yaitu standar yang menggambarkan status gizi balita, memperlihatkan bahwa balita BGM (bawah garis merah) di Provinsi DIY belum mencapai target. Kabupaten Bantul dan Gunungkidul masingmasing $1,6 \%$ dan $2 \%$, sedangkan 3 kabupaten/ kota yang lain $<1,5 \%(5)$.

Data laporan gizi balita yang didapat dari Kabupaten Bantul pada tahun 2011 adanya KEP total balita sebesar $11,31 \%$ meskipun sudah berada di bawah target nasional pada tahun 2015 sebesar $15 \%$. Balita gizi lebih sebesar $3,08 \%$, balita gizi baik sebesar $85,60 \%$, balita gizi kurang sebesar $10,79 \%$, balita gizi buruk sebesar $0,52 \%$. Wilayah Banguntapan termasuk tercatat sebagai salah satu kecamatan yang memiliki anak balita dengan status gizi buruk yang tertinggi sebanyak 28 kasus (10 lakilaki dan 18 perempuan) atau mencakup $41 \%$ kasus yang terjadi di Kabupaten Bantul(6).

Berdasarkan studi pendahuluan yang dilakukan di Puskesmas Banguntapan III diketahui bahwa pada tahun 2013 dilaporkan 0,24\% (4 balita) balita mengalami gizi buruk dari 1.602 balita yang ditimbang dengan tingkat kehadiran di Posyandu sebesar $63,9 \%$. Distribusi kasus gizi buruk ini terjadi di Dusun Jomblangan, Karangbendo dan Plumbon. Di antara ketiga dusun tersebut, hanya Dusun Karangbendo yang dalam 3 tahun terakhir ini memiliki kasus balita gizi buruk dan tingkat kehadiran posyandu yang cukup rendah $(48 \%)$. Tujuan penelitian ini untuk mengetahui hubungan antara tingkat kepatuhan kunjungan posyandu dengan status gizi balita di Posyandu Karangbendo, Banguntapan, Bantul, Yogyakarta.

\section{BAHAN DAN METODE}

Jenis penelitian menggunakan deskriptif analitik dengan studi observasional, dengan rancangan penelitian cross sectional. Populasi dalam penelitian ini adalah semua balita yang tercatat di Posyandu Karang Bendo tahun 2014 berjumlah 125 balita. Pengambilan sampel dilakukan dengan teknik accidental sampling dan dihitung menggunakan rumus sampel minimal sehingga diperoleh sampel minimal pada penelitian ini adalah 38 balita usia 1-5 tahun, sampel dalam penelitian ini yaitu 40 balita. Penelitian dilakukan di Posyandu Karangbendo Banguntapan pada tanggal 2 Juli 2014. Instrumen yang digunakan untuk mengumpulkan data penelitian berupa data sekunder dan pengukuran. Variabel bebas adalah tingkat kepatuhan kunjungan posyandu. Variabel terikat dalam penelitian ini adalah status 
gizi balita. Variabel pengganggu dalam penelitian ini yaitu asupan makanan, penyakit infeksi, ekonomi, pertanian, budaya, pendidikan, pengetahuan dan keterjangkauan pelayanan kesehatan.

\section{HASIL DAN BAHASAN}

\section{Karakteristik Sampel}

Karakteristik sampel berdasarkan umur dan jenis kelamin pada penelitian ini dapat dilihat pada Tabel 1 dan 2.

Tabel 1. Tabel Distribusi Frekuensi Sampel Berdasarkan Umur di Posyandu Karangbendo Banguntapan Tahun 2014

\begin{tabular}{lcc}
\hline Umur & f & \% \\
\hline 13-36 bulan & 28 & 70 \\
37-60 bulan & 12 & 30 \\
Jumlah & 40 & 100 \\
\hline
\end{tabular}

Sumber: Data Primer 2014

Tabel 1 menunjukkan bahwa balita yang menjadi sampel penelitian sebagian besar berumur antara 13-36 bulan yaitu 28 balita $(70 \%)$ dan berumur antara 37-60 bulan yaitu 12 balita (30\%).

Berdasarkan penelitian Pardede umur balita dari 13-36 bulan $(87,80 \%)$ merupakan umur yang paling berpengaruh dalam pertumbuhan balita(7). Berdasarkan hasil penelitian didapatkan bahwa usia balita antara ibu yang aktif ke posyandu dengan yang tidak aktif ke posyandu sama-sama besar yaitu ada usia balita 24-59 bulan.

Balita dalam kelompok umur ini merupakan masa rawan karena rentan terhadap kekurangan konsumsi zat makanan apalagi jika disertai dengan penghentian ASI mendadak dan pemberian makanan padat yang kurang memadai. Antibiotik pasif yang diperoleh melalui ASI akan menurun dan kontak dengan lingkungan akan semakin bertambah secara cepat dan menetap tinggi selama tahun kedua dan ketiga kehidupan(8). Masa ini mempunyai pengaruh cukup besar dalam pertumbuhan dan perkembangan anak. Anak membutuhkan perhatian khusus dari orang tua seperti pemenuhan kebutuhan gizi melalui perilaku orang tua dan pengasuh dalam hal kedekatannya dengan anak, memberikan kasih sayang, dan edukasi. Hal ini seperti yang diungkapkan oleh Suhardjo bahwa perilaku dan pola pengasuh merupakan salah satu faktor yang mempengaruhi status gizi balita(9).

Tabel 2 menunjukkan bahwa balita yang menjadi sampel penelitian sebagian besar berjenis kelamin perempuan yaitu 23 balita $(57,5 \%)$ dan sisanya berjenis kelamin laki-laki yaitu 17 balita $(42,5 \%)$.
Tabel 2. Tabel Distribusi Frekuensi Sampel Berdasarkan Jenis Kelamin di Posyandu Karangbendo Banguntapan Tahun 2014

\begin{tabular}{lcc}
\hline Jenis kelamin & f & \% \\
\hline Laki-laki & 17 & 42,5 \\
Perempuan & 23 & 57,5 \\
Jumlah & 40 & 100 \\
\hline
\end{tabular}

Sumber: Data Primer 2014

\section{Tingkat kepatuhan kunjungan}

Tingkat kepatuhan kunjungan posyandu balita pada penelitian ini dapat dilihat pada Tabel 3.

Tabel 3. Tabel Distribusi Frekuensi Sampel Berdasarkan Kepatuhan Kunjungan di Posyandu Karangbendo Banguntapan Bantul tahun 2014

\begin{tabular}{lcc}
\hline \multicolumn{1}{c}{ Tingkat kepatuhan } & f & \% \\
\hline Patuh & 28 & 70 \\
Tidak patuh & 12 & 30 \\
Jumlah & 40 & 100 \\
\hline
\end{tabular}

Sumber: Data Primer 2014

Tabel 3 menunjukkan bahwa balita yang menjadi sampel penelitian sebagian besar patuh dalam melakukan kunjungan yaitu 28 balita $(70 \%)$ sedangkan yang tidak patuh sebanyak 12 balita (30\%).

Penelitian Raharjo dalam Maulana, di Posyandu Desa Jendi Kecamatan Selogiri Kabupaten Wonogiri bahwa tingkat pendidikan dapat mempengaruhi ibu untuk aktif ke posyandu setiap bulannya(10). Berdasarkan hasil penelitian yang sudah dilakukan oleh Susanti dalam Octaviani jumlah balita yang terdapat di dalam keluarga mempengaruhi kunjungan ibu ke posyandu, dimana keluarga yang memiliki jumlah balita sedikit maka ibu akan lebih sering datang ke posyandu serta jarak dari rumah ke posyandu sangat mempengaruhi kunjungan ibu ke posyandu(11).

Upaya penanggulangan gizi buruk yang dapat dilakukan oleh keluarga yaitu mencakup tindakan pemantauan gizi buruk, pemberian PMT, pemberian suplementasi zat gizi, pemeriksaan dan pengobatan penyakit, peningkatan perilaku hidup bersih dan sehat (PHBS) serta mengikuti penyuluhan gizi dan kesehatan(12). Menurut Leavell dan Clark dalam Octaviani, health promotion (promosi kesehatan) kesehatan meliputi pemeriksaan selektif secara periodik, seperti pemeriksaan tumbuh kembang bayi secara rutin dan pendidikan kesehatan secara rutin(11).

Ibu yang tidak aktif berkunjung ke posyandu mengakibatkan ibu kurang mendapatkan informasi mengenai pentingnya status gizi balita, tidak mendapat dukungan dan dorongan dari petugas 
kesehatan apabila ibu mempunyai permasalahan kesehatan pada balitanya, serta pemantauan pertumbuhan dan perkembangan balita yang tidak dapat terpantau secara optimal, karena pemantauan pertumbuhan balita dapat dipantau melalui KMS. Menurut Sulistyorini, menyatakan bahwa KMS berfungsi sebagai alat bantu pemantauan gerak pertumbuhan bayi(13). KMS juga berfungsi untuk menilai status gizi bayi. Kegiatan posyandu salah satunya adalah menimbang bayi, kemudian diikuti dengan pengisian KMS berdasarkan berat badan dengan umur sehingga dapat diketahui dengan segera bila terdapat kelainan atau ketidaksesuaian dengan gerak pertumbuhan pada KMS.

\section{Status Gizi Balita}

Status gizi balita pada penelitian ini dapat dilihat pada Tabel 4.

Tabel 4. Tabel Distribusi Frekuensi Sampel Berdasarkan Status Gizi Balita di Posyandu Karangbendo Banguntapan Tahun 2014

\begin{tabular}{lcc}
\hline \multicolumn{1}{c}{ Status gizi } & $\mathbf{f}$ & $\%$ \\
\hline Buruk & 0 & 0 \\
Kurang & 10 & 25 \\
Baik & 29 & 72,5 \\
Lebih & 1 & 2,5 \\
Jumlah & 40 & 100 \\
\hline
\end{tabular}

Sumber: Data Primer 2014

Tabel 4 menunjukkan bahwa balita dengan status gizi lebih yaitu 1 balita $(2,5 \%)$, status gizi baik sebanyak 29 balita (72,5\%), status gizi kurang sebanyak 10 balita (25\%) dan balita dengan status gizi buruk tidak ada ( $0 \%)$.

Berdasarkan hasil Riskesdas, prevalensi gizi baik di Indonesia sebesar $68,5 \%$ dan gizi kurang $13,9 \%$. Prevalensi gizi baik di Provinsi DIY sebesar $87,91 \%$ dan gizi kurang sebesar $8,45 \%$. Prevalensi gizi baik di Kabupaten Bantul sebesar $85,60 \%$ dan gizi kurang sebesar 10,79\%(2).

Menurut penelitian Bonaventura faktor yang berperan dalam menentukan status gizi adalah tingkat sosial ekonomi, dalam hal ini daya beli keluarga. Kemampuan keluarga untuk membeli bahan pangan antara lain tergantung pada besar kecilnya pendapatan dan pengeluaran, harga bahan makanan itu sendiri, serta tingkat pengelolaan sumber daya lahan dan pangan. Antara penghasilan dan status gizi, ada hubungan yang sangat terkait(14).

Pengaruh peningkatan dari penghasilan akan berdampak pada perbaikan status gizi dan kondisi keluarga. Umumnya bila pendapatan meningkat maka jumlah dan jenis makanan cenderung akan membaik juga. Tingkat penghasilan akan menentukan jenis pangan apa yang akan dibeli dengan uang tersebut. Semakin tinggi penghasilan, semakin tinggi pula persentase yang digunakan untuk membeli buah, sayur dan berbagai jenis makanan yang lain(15).

Menurut Suhardjo faktor penyebab langsung timbulnya masalah gizi buruk pada balita adalah adanya penyakit infeksi serta konsumsi makanan yang tidak mencukupi kebutuhannya, sedangkan faktor penyebab tidak langsung merupakan faktor penunjang timbulnya masalah gizi buruk pada balita adalah kurangnya pengetahuan ibu tentang kesehatan, sosial ekonomi (daya beli) yang masih rendah, ketersediaan pangan ditingkat keluarga yang tidak mencukupi, pola konsumsi yang kurang baik, serta fasilitas pelayanan kesehatan yang masih sulit dijangkau(8). Hal ini juga sesuai dengan teori yang dikemukakan oleh Supariasa menyatakan ada dua penyebab yang menyebabkan timbulnya masalah gizi buruk. Menurut Supariasa, faktor penyebab tidak langsung salah satunya yaitu pemeliharaan kesehatan(16).

\section{Hubungan Tingkat Kepatuhan Kunjungan Posyandu dengan Status Gizi Balita}

Hubungan tingkat kepatuhan kunjungan posyandu dengan status gizi balita dalam penelitian ini dapat dilihat pada Tabel 5.

Hasil analisis Kendall Tau antara tingkat kepatuhan kunjungan posyandu dengan status gizi balita diketahui nilai $z$ sebesar 0,614 . Berdasarkan taraf signifikan $5 \%$ maka diketahui $z$ tabel $=0,185$ dengan taraf signifikan $0,000(p<0,05)$ yang artinya Ho ditolak karena $z$ hitung $\geq z$ tabel yaitu $0,614 \geq$

Tabel 5. Tabel Silang Tingkat Kepatuhan Kunjungan Posyandu dengan Status Gizi Balita di Posyandu Karangbendo Banguntapan Tahun 2014

\begin{tabular}{|c|c|c|c|c|c|c|c|c|c|c|c|c|}
\hline \multirow{3}{*}{$\begin{array}{l}\text { Kepatuhan } \\
\text { Kunjungan }\end{array}$} & \multicolumn{8}{|c|}{ Status gizi balita } & \multirow{2}{*}{\multicolumn{2}{|c|}{ Jumlah }} & \multirow{3}{*}{$\chi_{\text {hitung }}$} & \multirow{3}{*}{$\chi_{\text {tabel }}$} \\
\hline & \multicolumn{2}{|c|}{ Buruk } & \multicolumn{2}{|c|}{ Kurang } & \multicolumn{2}{|c|}{ Baik } & \multicolumn{2}{|c|}{ Lebih } & & & & \\
\hline & $f$ & $\%$ & $f$ & $\%$ & $f$ & $\%$ & $f$ & $\%$ & $f$ & $\%$ & & \\
\hline Patuh & 0 & 0 & 2 & 5 & 25 & 62,5 & 1 & 2,5 & 28 & 70 & & \\
\hline Tidak patuh & 0 & 0 & 8 & 20 & 4 & 10 & 0 & 0 & 12 & 30 & 0,614 & 0,185 \\
\hline Jumlah & 0 & 0 & 10 & 25 & 29 & 72,5 & 1 & 2,5 & 40 & 100 & & \\
\hline
\end{tabular}

Sumber: Data Primer, 2014 
0,185 artinya ada hubungan antara tingkat kepatuhan kunjungan posyandu dengan status gizi balita.

Semakin patuh balita berkunjung ke posyandu, maka status gizi balita akan baik juga. Hal ini dapat dilihat dari balita yang patuh berkunjung ke posyandu memiliki persentase status gizi baik yang lebih tinggi $(62,5 \%)$ dibanding yang tidak patuh (10\%). Sebaliknya balita yang mempunyai kepatuhan rendah memiliki persentase status gizi kurang yang lebih tinggi $(20 \%)$ dibanding yang patuh $(5 \%)$.

Perilaku kesehatan terhadap sistem pelayanan kesehatan merupakan perilaku seseorang menyangkut respons terhadap fasilitas pelayanan, cara pelayanan, petugas kesehatan, dan obat-obatannya yang terwujud dalam pengetahuan, persepsi, sikap dan penggunaan fasilitas, petugas, dan obat-obatan(17). Kesadaran ini sesuai dengan teori perilaku kesehatan yang meliputi pengetahuan (knowledge), sikap (attitude), dan tindakan atau praktik (practice)(18).

Dalam penelitian Asdhany di Posyandu Kelurahan Cangkringan Kecamatan Mijen Kota Semarang bahwa tingkat partisipasi ibu dalam kegiatan posyandu mempengaruhi status gizi anak balita berdasarkan BB/U(19).

Menurut Octaviani menunjukkan adanya hubungan yang signifikan antara variabel keaktifan keluarga dalam kegiatan posyandu dengan status gizi balitanya. Keluarga yang tidak aktif dalam kegiatan posyandu mempunyai risiko 6,857 kali lebih besar terkena status gizi KEP dibandingkan dengan keluarga yang tidak aktif(11).

Hasil penelitian ini sesuai dengan penelitian yang dilakukan oleh Maulana di Desa Soko Jember Kecamatan Jelbuk Kabupaten Jember yaitu didapatkan hubungan yang positif antara keaktifan ibu dalam posyandu dengan penurunan jumlah balita BGM yaitu ibu yang aktif dalam posyandu dapat menurunkan jumlah balita BGM(10).

\section{SIMPULAN DAN SARAN}

Simpulan dalam penelitian ini adalah balita yang patuh berkunjung ke Posyandu Karangbendo Banguntapan sebesar $70 \%$, sedangkan balita tidak patuh berkunjung ke posyandu sebesar $30 \%$. Balita yang berkunjung di Posyandu Karangbendo Banguntapan sebagian besar termasuk dalam kategori status gizi baik (72,5\%). Ada hubungan antara tingkat kepatuhan kunjungan posyandu dengan status gizi balita di Posyandu Karangbendo Banguntapan Bantul Yogyakarta. Saran bagi orang tua yang memiliki balita agar meningkatkan kepatuhan kunjungan Posyandu untuk meningkatkan status gizi balita.

\section{RUJUKAN}

1. Radiansyah E. Penanggulangan Gizi Buruk. Purworejo: Dinas Kesehatan RI; 2007.

2. Kementrian Kesehatan RI. 2013. Riset Kesehatan Dasar 2013. Jakarta: Kementrian Kesehatan RI.

3. Kementrian Kesehatan RI. 2010. Riset Kesehatan Dasar 2010. Jakarta: Kementrian Kesehatan RI.

4. Kemenkes RI. Profil Direktorat Jendral Gizi dan KIA. Jakarta: Kemenkes RI; 2011.

5. Kemenkes RI. Profil Kesehatan Provinsi DIY 2013. Yogyakarta: Pemerintah Dinas Kesehatan Kabupaten Bantul; 2013.

6. Dinas Kesehatan Kabupaten Bantul. Profil Kesehatan 2012. Bantul: Pemerintah Dinas Kesehatan Kabupaten Bantul; 2012.

7. Pardede PM. Hubungan Faktor-Faktor Internal terhadap Kunjungan Posyandu di Kelurahan Sumurboto Kecamatan Banyumanik Wilayah Kerja Puskesmas Ngesrep. Series online. 2010 [cited 2014 Jul 28]. Available from: http://digilib. unimus.ac.id/gdl.php?mod=browse \&op=read\&i $d=$ jtptunimus-gdlpintau lime-5346.

8. Supartini Y. Buku Ajar Konsep Dasar Keperawatan Anak. Jakarta: EGC; 2004.

9. Maulana A. Hubungan Keaktifan Ibu Dalam Posyandu Dengan Penurunan Jumlah Balita Bawah Garis Merah Di Desa Soko Kecamatan Jelbuk Kabupaten Jember. Jember: Universitas Jember; 2013.

10. Oktaviani, dkk. 2008. Hubungan Keaktifan Keluarga Dalam Kegiatan Posyandu Dengan Status Gizi Balita Di Desa Rancaekek Kulon Kecamatan Rancaekek Kabupaten Bandung. Jurnal. [internet]. 2008 [cited 2014 Feb 28]. Available from: http://pustaka.unpad.ac.id/ archives/29949/.

11. Suharjo. Berbagai Cara Pendidikan Gizi. Jakarta: Bumi Aksara; 2003.

12. Kementrian Kesehatan RI. Pedoman Penanggulangan Kekurangan Energi Protein (KEP) dan Petunjuk Pelaksanaan PMT pada Balita. Jakarta: Kementrian Kesehatan RI; 2007.

13. Sulistyorini,dkk. Posyandu dan Desa Siaga. Bantul: Nuha Medika; 2010.

14. Bonaventura YA. Hubungan antara tingkat partisipasi ibu Di posyandu dengan status gizi balita. Semarang: Universitas Diponegoro; 2011. 
15. Sjahmien M. IImu Gizi 2 Penanggulangan Gizi Buruk. Jakarta: Papas Sinar Sinanti; 2003.

16. Supariasa. Penilaian Status Gizi. Jakarta: Buku Kedokteran EGC; 2002.

17. Notoatmojo S. Promosi Kesehatan dan IImu Perilaku. Jakarta: Rineka Cipta; 2007.

18. Notoatmojo S. Metodologi Penelitian Kesehatan .Jakarta: Rineka Cipta; 2010.
19. Asdhany C, Kartini A. Hubungan Tingkat Partisipasi Ibu dalam Kegiatan Posyandu dengan Status Gizi Anak Balita (Studi di Kelurahan Cangkiran Kecamatan Mijen Kota Semarang. Journal of Nutrition College. [serial on line]. 2012 [cited 2014 Apr 18]. Available from: http:// ejournal-s1.undip. ac.id/index.php/jnc/article/view/424/424. 